\title{
The Organizational Identification Perspective of CSR on Creative Performance: The Moderating Role of Creative Self-Efficacy
}

\author{
Muhammad Ibrahim Abdullah ${ }^{1, *}$, Samra Ashraf ${ }^{1}$ and Muddassar Sarfraz ${ }^{2}$ \\ 1 Department of Management Sciences, COMSATS Institute of Information Technology Lahore, Lahore 54000, \\ Pakistan; samraashraf05@gmail.com \\ 2 Business School, Hohai University, Nanjing 210098, China; muddassar.sarfraz@gmail.com \\ * Correspondence: miabdullah@ciitlahore.edu.pk
}

Received: 19 October 2017; Accepted: 14 November 2017; Published: 18 November 2017

\begin{abstract}
Corporate social responsibility (CSR) is an emerging and fast-growing concept for both academic research and organizations. In recent years, the far-reaching influence of CSR practices on stakeholders has made both researchers and practitioners pay heed to this dimension. Employees are one of the most important stakeholders influenced by CSR practices. CSR brings in many ideas, concepts, and techniques. In the past, different antecedents and consequences of corporate social responsibility have been studied, but there is still a deficit in regard to whether employee creative performance is an outcome of corporate social responsibility, and the interlinked variables that might enhance this relationship. The main objective of this study is to examine how CSR practices enhance employee performances within the organization, and which other variables may enhance this relationship. The literature suggests that employees who value CSR campaigns and other practices identify with their company to a greater degree, work with more devotion and loyalty, and show more creativity in their work performance. In this study, organizational identification has been taken as the mediator, and creative self-efficacy has been taken as the moderator. The hypotheses were tested within the sample of companies engaging in CSR practices in Pakistan. A questionnaire survey was conducted using simple random sampling. Simple linear regression, hierarchical regression, and Barron and Kenny tests were applied through SPSS (Statistical Package for the Social Science) for data analysis, and results were found according to the proposed model of the study.
\end{abstract}

Keywords: corporate social responsibility; CSR; organizational identification; creative self-efficacy; creative performance; Pakistan

\section{Introduction}

Corporate social responsibility (CSR) is a concept that has had a significant influence on business missions, management, operations, and marketing [1]. CSR brings ideas, concepts, and techniques [2]. CSR organizations are converting the trend of a "single bottom line" philosophy (economic outcomes) to the most commonly referenced term "triple bottom line" (economic, social, and environmental outcomes) [3]. This move encourages organizations to take steps beyond the scope of the profit-seeking organization towards environmental safety, supporting education, and involvement in the social welfare [4,5]. CSR restrains any negative impact of the organizations in their target market, and develops loyalty for that organization within the society.

CSR is a progressively critical aspect of strategic organizational management due to evolving demands and pressures from various stakeholder groups [6]. A host of stakeholders, e.g., employees, clients, suppliers, managers, shareholders, communities, etc., have an impact on any organization, and together have a legal and moral right to the organization [7]. Therefore, the human resource 
management of any organization should focus on exploring and implementing the vital role of CSR in its stakeholder activities, primarily those related to employees' outcomes.

At the moment there is a lack of managerial implications, which might be because there has been less discussion in the literature of the factors that underpin the links between CSR and firm performance. This deficit is being filled as scholars pay attention to the effects of CSR from the stakeholder perspective [8]. Scholars are analyzing the influence of CSR on the attitudes and behaviors of major organizational stakeholders, including skilled employees $[9,10]$.

Employee engagement is being ensured as CSR becomes embedded in the organization [11]. It has been demonstrated that employee engagement works as a very useful antecedent towards achieving the goals and objectives of any organization [12]. Human resource management (HRM) is considered fundamental to the success of organizations, as it develops and implements the creativity and improves performance overall [13]. Davies [14] studied the HRM practices utilized by Small and medium-sized enterprises in embedding CSR, as he considered the role of employee engagement in the management of CSR still underexplored.

Stakeholders usually prefer companies to run their business activities in compliance with social responsibility [15], and employees are the most critical stakeholder whose responses to CSR have impactful meaning for the organization [16]. Unfortunately, only a few studies have focused on how companies' stakeholders, especially employees, may respond to socially responsible business practices. Jones' [17] findings suggest that employees who value CSR campaigns and other practices have a higher degree of identification with their company, because it makes them feel prouder about their organizational membership. They ultimately have stronger intentions to stay in the organization, with more engagement and loyalty due to the enhanced corporate identification. Job performance does not influence employee perceptions of CSR.

CSR has the potential to persuade a variety of attitudes and behaviors among employees, especially organizational identification (OID) $[18,19]$. Researchers have outlined some of these behaviors, which include job satisfaction, job commitment [20], trust [9], and employee attraction and retention [21,22]. A few researchers have also mentioned that there is a need to understand how CSR persuades employees to work with more devotion in a way that leads to achieving the organizational objectives [23]. Some other researchers are of the view that there is a deficit in the literature regarding CSR as to how it builds up creativity among employees [24]. Moreover, creativity in employee performance is essential for organizations, because it is a vital and fundamental factor to group and organizational-level performance and competitive advantage [25]. Some companies are using different sources such as sustainability reports for the disclosure of CSR information, while there is a different scenario in developing and developed countries.

\section{Statement of the Problem}

For many years, there has been a wide range of research on the association between CSR and organizational performance, but still, there is a deficit regarding the intermediate variables affecting the relationship between CSR and performance [26]. There is evidence that employee satisfaction, loyalty, motivation, and job commitment are the outcomes of CSR, but there is lack of explanation of the mechanisms and processes that lie between the relationship of CSR and performance, particularly concerning employee creativity because of CSR [24]. On the other side, organizations are focusing on creativity in employee performance for better career development and innovation [27]. The leaders of today's era are facing the challenge of indulging the employees in creative work performance activities [28].

However, very few studies have discussed the antecedents of creativity. For example, Madjar [29] et al. have empirically examined how employees' positive mood states and creative personality characteristics mediate and moderate innovative performance, respectively. Zhu [26] studied the role of ethical leadership in firm performance, linking the antecedents and outcomes of CSR. Gong [30] scrutinized the positive relationship between employee creativity and job 
performance with the help of two learning-related personal and situational variables. These variables were employee learning orientation and transformational leadership, which had a collaborative effect on employee creativity through employee creative self-efficacy.

Benjamin and Flynn [31] chose transformational leadership and employee learning orientation as predictors of employee creativity, because both of these variables have the potential to build up the creative proficiency among employees through learning different approaches, which enhances artistic ability [32]. Researchers have also used various imminent variables of employee creativity; for example, Farmer [33] discussed the impact of creative role identity-making on innovative performance. George and Zhou [34] were concerned with mood states; Oldham and Cummings [35] examined job complexity; Shalley [36] regarded creativity goals as the antecedents to creative performance.

According to the research, high levels of employee self-efficacy and work engagement are excellent predictors of creative performance [37]. CSR has a direct positive influence on employee creativity, but OID alone has a minimal enhancing effect, and cannot fully explain why and how CSR develops employee creativity. Thus, OID is probably just one influencing factor among others [24]. That is why creative self-efficacy has been taken as the augmenting factor, along with organizational identification, to enhance the effect of CSR on innovative performance. CSR disclosure has a positive relationship with family ownership and industry [38]. Organizational citizenship behavior has influenced employee perceptions of CSR toward social and non-social stakeholders [39]. CSR, employee performance, and employee cost have a positive relationship [40].

\section{Literature Review}

CSR is a new and evolving concept in research, where it has featured prominently in the 1990s and 2000s. CSR has been a very debatable concept for a prolonged time, but a leading light has been shined on the CSR since the mid-20th century. However, the interest of business organizations in society is an ancient concept [41]. In the late 19th century, the philanthropy concept was for individuals, businesses, or both. According to Carroll [41], before 1950 organizations and business proprietors took many initiatives to use their resources to stand by social causes, such as charity or lending money for different social activities. Thus, organizational actions for social welfare can be seen before 1950, but these measures were not known as social responsibility. The CSR concept also has a major influencing part of business missions, management, and operations, as well as in marketing all over the world [1]. Peter Lund-Thomsen stated that companies are trying to become more socially and environmentally-friendly. There are several hazards in the implementation of CSR policies and environmental risk management strategies [42].

\subsection{Organizational Identification}

Organizational identification develops when an employee relates himself/herself to the organization, and wants to continue the rest of his/her career with that organization [43]. According to some other researchers, OID confirms an employee's perceptions of the organizational values (Pratt, 1998). Based on the social identity theory by Ashforth and Mael [44], OID is the similarity and affective belongingness of employees with the organization in which they are working. It has also been described as the employee's membership in the organization [45]. Cognitive, affective, and evaluative perspectives of OID have been summarized in social identity theory by Tajfel and Turner, such as for example, perceptual, emotional, and affective belongingness [46]. Therefore, OID has been operationalized in this study as the employees' intention to work in the current organization with more devotion and care. Employees show loyalty to warm feelings, and continue working with great happiness and an affinity with the beliefs, values, and norms of the organization [47].

O'Reilly and Chatman [48] scrutinized OID as emotional belongingness and motivational phenomena that make an employee remain in the organization with more satisfaction and a self-fit belief in the organization. OID also reflects the expression of an employee's attributes according to 
his/her perception of the organization [49]. The theoretical and empirical analysis also explains OID as the comparison of personal-self and organizational-self [50].

Four perspectives of OID have been clarified in this study. First, a high level of identification develops among employees who prefer the CSR activities of their organization [17]. Second, identification has been taken as relational and comparative with any organization other than the workplace [44]. Third, keeping in view this relational and relative notion of OID, social identity theory explains that employees identify with their organization to enhance their self-confidence and self-esteem [51]. Thus, employees perceive their social identities positively when they belong to a well-reputed organization [52]. Fourth, the increased level of OID among employees helps them engage in better creative work performance [24]. Organizational identification drives employees' job performance, and has effects on organizational identification and customer orientation [53].

\subsection{Social Identity Theory}

According to social identity theory, individuals' positive self-concept is developed when they feel membership with a specific group or organization [46]. Additionally, Tajfel and Turner [46] explain that positive social identity is aroused when employees identify with their current group, which is called an in-group, more confidently and satisfactorily as compared with other teams, which are called an out-group. For the sake of building up and maintaining a positive self-concept, the in-group must have the potential to be distinguished from out-groups by unique and favorable aspects. Individuals preferably desire to belong with a favorable and helpful in-group; otherwise, they tend to move towards another out-group with more satisfying perceived conditions. Process of social identification also makes the employees to share a common destiny and experience whether in the form of successes or failure [54]. Therefore, the definitive focus of organizations is to gain and maintain a unique superiority and competitive edge over out-groups. As such, individuals tend to prefer to be the part of and identify with well-reputed and high-status organizations or other groups, rather than the organizations or groups with less reputation or status [55].

An application of social identity theory to organizations by Mael and Ashforth [56] suggests that individuals feel more confident working with organizations that are perceived as prestigious by outsiders. This means that more exalted organizations increase the level of attachment and self-confidence of their employees through the process of social identification [56]. The organizational success creates a demand from outsiders to work within such an organization, which in turn increases their employees' positive perception and identification with the organization. Employees bathe in the reflected glory of the organization, which leads to desirable outcomes, such as citizenship behaviors (Dutton et al., 1994). In contrast, organizational failure or a negative impact on outsiders creates depression, stress, disengagement, and less involvement in work roles and job performance amongst employees [49]. The activities or resources which fulfill the individual's social and self-esteem needs are called Socio-emotional resources [57].

Individuals tend to get feedback about themselves or their organization from outsiders or society [58]. Specifically, employees evaluate their worth or standard through the perception of outsiders about their organization [59]. Social identity theory also explained that the self-concept of individuals relates their identity to their abilities and interests, which becomes the basis for social identity classifications [46]. Individuals classify themselves and others into various standard groups after self-conceptualization and self-evaluation through the prototypical characteristics perceived by themselves or by outsiders.

\subsection{Group Engagement Model}

OID leads directly to employee engagement, according to the group engagement model [60]. The group engagement model states that individuals mold their behaviors and attitudes due to social identification with the group. Specifically, in the context of this study, this model suggests that when individuals strongly identify with the organization, it matches their self-concept, and makes 
them intrinsically much more motivated to work with more engagement, devotion, and better performance [60]. The group engagement model also explains that individuals who strongly identify with the organization are concerned with the fate and success of their organization, and therefore exhibit extra efforts and positive behaviors and attitudes for the organizational success. CSR policies are helpful in enhancing labor agency. A company's production and CSR tend to have a limited impact on facilitating worker agency [61].

\subsection{Creative Cognition Approach}

Finke [62] presented the "Geneplore" model; according to this model, creativity comprises two phases: a generative phase and an exploratory phase. In the first stage, the individuals tend to construct cognitive structures called pre-inventive structures. In this phase, employees' creative self-efficacy plays a vital role. Then, in the second phase, which is an exploratory phase, the individuals act upon their imaginary structures and come up with creative ideas. Research also suggests that individuals show high creative performance through their different imaginations of developing new ideas with the help of properties of existing categories and concepts [63]. Weisberg [64] also explains that employees engage in ordinary cognitive activities, and come up with extraordinary creative performance.

\subsection{Self-Efficacy Theory}

Self-efficacy theory is an important component that lies at the center of Bandura's social cognitive theory, which suggests a high interrelation between an individual's behavior, environment, and cognitive factors. According to Staples [65], self-efficacy theory suggests four major sources of information for self-efficacy evaluation by individuals. The first is based on an individual's performance accomplishments. Employees' goal achievements increase their confidence, expectations of mastery, and self-efficacy. The second source is related to the modeling component of social cognitive theory, whereby employees gain experience and the confidence to improve their performance through the observation of others' successful activities. The third source is social persuasion, in which employees are motivated and given positive feedback from their supervisors on their incremental improvements in performance. Such coaching and motivation raise their self-efficacy to cope successfully with specific tasks. The fourth source is the individual's physiological or emotional states, which influence self-efficacy judgments concerning specific tasks.

\subsection{CSR in Pakistan}

Most of the research literature regarding CSR is found in developed countries, while developing countries lack research on CSR. CSR practices have become essential for organizations to gain long-term success by including ethical and responsible attitudes in the formulation of managerial strategies. In the great competition of the modern era, every organization should meet the expectation of employees and other stakeholders. Therefore, every successful organization wants to become a well-reputed workplace in the view of society [66]. Keeping this in view, some multinational companies and domestic organizations in developing countries are adopting CSR practices in their long-term strategies [67]. For example, in Pakistan, companies are informally doing CSR activities [68].

According to definitions by European Commission (EC) and World Business Council for Sustainable Development (WBCSD), CSR is assimilating the economic, social, and environmental aspects of any business, and causes long-term and sustainable development. People in some developing countries are deprived of even the basic needs of life, such as drinkable, clean, water, food, shelter, etc. CSR can help improve these conditions. Therefore, more than $60 \%$ of companies contribute their part in CSR through community development, charity, and donations for various human activities related to well-being [69].

There is not any proper universal definition of CSR. Therefore, CSR is being perceived and practiced in various ways in different countries. The challenges in different aspects of CSR practices 
in developed and developing countries are somewhat the same, but the low per capita income and other environmental, human, and social issues in some countries create differences in CSR implementations [70]. Companies are involved in different CSR activities. These activities are conducted formally and informally, but SMEs approach towards CSR is unstructured in Pakistan [68].

The CSR concept in Pakistan focuses on corporate benevolence or compassion, social well-being, and community development 66. In 2013, companies started to adopt CSR disclosure policies after CSR voluntary guidelines. This disclosure is different from sector to sector [71]. There is also a growing awareness of the importance of environmental safety and protection in Pakistan. Many organizations are running different campaigns regarding the environment and health promotion every year. Some advocacy associations, such as for example, the National Forum of Environment and Health (NFEH), present excellence awards annually to companies that are showing the best performance in environment, health, education, and socio-economic development, or other welfare projects. Table 1 shows the recent advancements of these awards annually.

Table 1. Annual Environment Excellence Awards.

\begin{tabular}{ccc}
\hline Year & Nominations & Awards \\
\hline 9th Annual Environment Excellence Awards 2012 & More than 87 & 36 \\
10th Annual Environment Excellence Awards 2013 & More than 140 & 75 \\
11th Annual Environment Excellence Awards 2014 & More than 186 & 70 \\
12th Annual Environment Excellence Awards 2015 & Not known & 50 \\
\hline
\end{tabular}

The recognition of the significance of CSR is comparatively low in Pakistan, which could be why Pakistani products and brands are not yet earning excellent reputations in the international market. There is an exceptional need to raise the knowledge of CSR and run businesses more ethically in Pakistan [66].

Various organizations in Pakistan have established partnership agreements with different non-profit organizations or non-governmental organizations (NGOs) for better business sustainability. Such kinds of coalitions are called as "green alliances" [72]. However, there is less knowledge in Pakistan about the soft skills required to form green alliances in organizations, such as moral and responsive work attitudes, and environmental and health responsibilities, compared with other developed countries. So, it cannot be denied that CSR practices are gradually growing in popularity in Pakistan, though they are still in the initial stages [66].

\section{Conceptual Model and Hypotheses Development}

The significant dimension of this study is CSR. The CSR concept has considerable influence on business missions, management, operations, and marketing all over the world [1]. CSR is conceptualized as the "sum of economic, legal, ethical, and discretionary expectations that society has of organizations at a given point in time" [73]. CSR refers to responsibilities regarding customers, employees, shareholders, the environment and society; these responsibilities all together have a positive impact on organizational identification. OID is conceptualized as "the degree to which a member defines him or herself by the same attributes that he or she believes define the organization" [49]. OID can be defined as an employee's intention to work in the current organization with more devotion, care, and loyalty. Organizational identification mediates the relationship between CSR and creative performance, with the moderating effect of creative self-efficacy.

Figure 1 explains the theoretical framework of the study. There are six hypotheses in this research. The primary dimension of this research is CSR. Creative performance is a dependent variable in this model. Creative performance is the outcome of new and innovative ideas, products, or procedures that are novel or original and potentially useful to the employing organization. Organizational identification mediates the relationship between CSR and creative performance, generating the moderating effect of creative self-efficacy. 


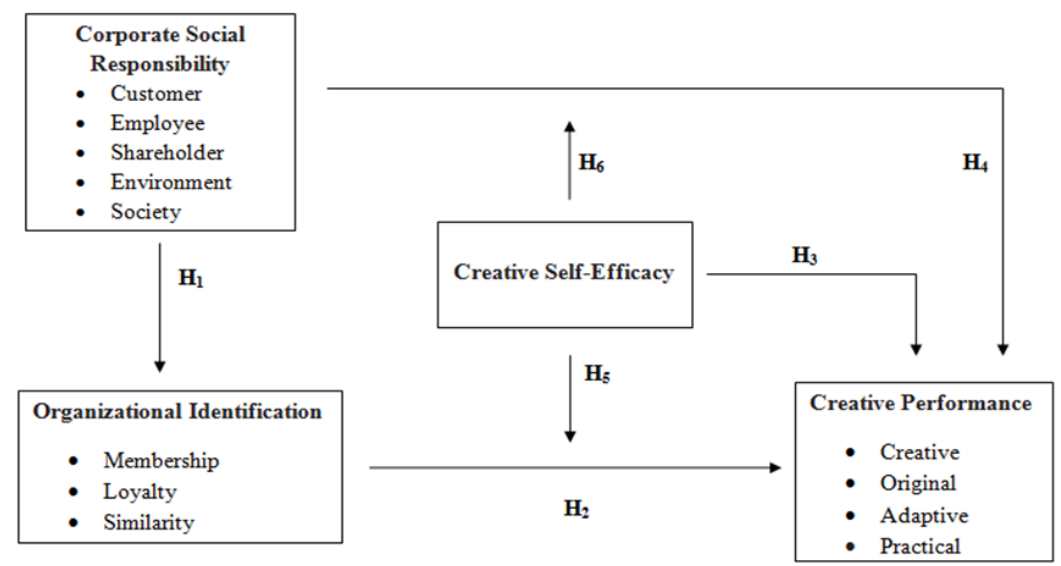

Figure 1. Theoretical Framework.

The Fatma [74] scale, which contains 17 items in total, has been adopted in this research. It is further categorized into five sub-dimensions of CSR. Organizational identification assessment has been accomplished through the means of a scale created by Mael and Ashforth [56]. The scale constitutes six items regarding membership, loyalty, and similarity, in which employee pride in membership, and an affective state of loyalty for employees with their organization are respectively manifested, as well as similarities as to which employees empathize with the organization over the fate, beliefs, values, and norms within it. Creative performance has been assessed using three items developed by Oldham and Cummings [35] regarding employees' creative, original, adaptive, and practical work. A scale for creative self-efficacy consisting of four items was adopted from Tierney and Farmer [33], and it is pertinent to how much confidence employees demonstrate in their efficiency in problem-solving and generating creative ideas.

\subsection{CSR and OID}

Stakeholders have an impact on any organization, as they altogether have legal and moral rights to the organization [7]. CSR embraces a wide range of citizenship behaviors, such as being environmentally friendly, ensuring employee welfare benefits, protecting shareholder rights, and engaging in those types of public activities that are deemed worthy and legitimate according to the organization's legal and ethical standards.

Stakeholders usually prefer companies that run their business in compliance with social responsibility [15], and employees are the most crucial stakeholder whose responses to CSR have impactful meaning for the organization [16]. There is debate as to whether employee engagement works as a very useful antecedent towards achieving the goals and objectives of any organization [12]. The philanthropic aspect of CSR refers to the voluntary contribution of organizations to charity or community welfare, but not doing so does not mean unethical behavior.

Organizational identification (OID) develops when an employee believes that his/her organization's value and norms are same as that of his/her self-beliefs [75,76]. From the employees' perspective, there is a direct and positive link between employees' perception about the organization's CSR and their level of organizational commitment, because if they perceive their organization's reputation as highly rated due to CSR, then they express more job commitment [67]. Boyd [77] also suggests that a favorable organizational reputation has the potential to influence better performance, because overall it increases the level of satisfaction and loyalty of investors [78], employees, customers [79], and other stakeholders. Therefore, there is a direct and positive association between organizational CSR practices and employee OID [18]. CSR perceptions also meet employees' relational and psychological needs, which creates satisfaction [24]. Bauman and Skitka [80] argue that CSR is a good precursor to stronger OID among employees through raising the perceived organizational 
attractiveness and status expressed by outsiders, which leads to an increased sense of belongingness and affiliation within the organization. Ultimately, well-built positive CSR is liable to promote employee OID, because it communicates a commitment to values that employees share.

Hypothesis 1 (H1): There is a positive relationship between corporate social responsibility and organizational identification.

\subsection{OID and Creative Performance}

OID facilitates many inspirational employee behaviors and attitudes [40-81]. OID among employees directs the creativity in their performance [24]. Organizations are inclined to focus on employee creativity for competitive advantage, adaptation, and survival [82]. Creativity in employee performance is also essential for organizations, because it is a necessary and fundamental factor for the group [25]. It is essential to determine both the antecedents and consequences of employee creativity [83].

A high degree of OID, along with job security, encourages employees to become more curious and receptive to challenges and risks, and exhibit extra cognitive openness and greater task persistence [84]. Stronger OID also motivates employees to behave positively towards organizational strategies, practices, goals, and objectives [85]. Prior research also supports the relationship between OID and creativity. Employees with high OID show more loyal attitudes in their work in relation to the organizational success [44].

Hirst [86] analyzed the role of leadership in organizational identification, and its impact on creative performance through a social identity analysis of leadership [87]. Employees' creative performance is a way for them to contribute toward organizational success in work environments where creativity is essential for the job [88]. Inspirational motivation strengthens the association between organizational identification and creative performance, especially where creative performance is considered valuable for the organization [86].

Hypothesis 2 (H2): There is a positive relationship between organizational identification and creative performance.

\subsection{Creative Self-Efficacy and Creative Performance}

Creative self-efficacy is a new concept in the research of creativity [89]. It is a developing and emerging variable in creative studies [90]. Creative self-efficacy also imitates the employees' intrinsic motivation to perform creative roles. It can be used as a powerful precursor to creativity [30]. Self-efficacy has been found to be a vital driver of performance in a variety of task domains. Employee creative self-efficacy is the psychological mechanism behind creativity. Employees tend to be more creative when they have higher levels of creative self-efficacy [91,92]. Employees exhibit high-quality creativity when they hold high levels of work engagement, self-efficacy, autonomy, support, and appropriate resources. Proficient and competent employees are expected to have a high level of self-efficacy, which is necessary for the improved and enhanced level of employee creative performance [27-37].

Ma [93] finds creative self-efficacy to be an important factor influencing an individual's creative performance. According to Hall and Hall [94], polychronic people are those who tend to engage in more than one activity at the same time. Many factors influence an individual's creative performance, such as for example, external influences such as teamwork, supervision, training, and appreciation, as well as internal aspects such as creative personality, ability, and confidence [37]. Individuals with more creative personalities and creative self-efficacy tend to give more creative performances than those with adaptive personalities [95]. 
Self-awareness and self-confidence are necessary for an individual's creative performance. Oldham and Cummings [35] explain that employees must have creative proficiency in performing creatively. They also clarify that creative performance must be novel and original in the sense that it should be useful for the organization [35]. Complex jobs with more soft and cognitive skills require more flexibility and innovation. Employees need to have a greater ability to work creatively. Tierney and Farmer 33 found a positive relationship between creative self-efficacy and creative performance in both manufacturing and high-tech companies. Houghton and DiLiello [96] found that creative self-efficacy was positively related to individual creativity. Empirical evidence also supported the influence of self-efficacy beliefs on creative development and growth [97].

Hypothesis 3 (H3): There is a positive relationship between creative self-efficacy and creative performance.

\subsection{CSR, Creative Performance, and OID}

CSR is viewed as an important aspect of firm-level strategy due to evolving demands and pressures from various stakeholder groups [6]. Scholars have recently focused their attention on the benefits of CSR [98]. Researchers found a positive association between CSR and firm performance $[99,100]$. Zhu [26] studied the role of ethical leadership in linking the antecedents and outcomes of CSR on firm performance. He pointed out that there has long been a wide range of research on the association between CSR and organizational performance, but still there is a deficit regarding the intermediate variables that affect the relationship between CSR and performance [26].

Organizations are focusing on creativity for better career development and innovation [101]. Carmeli and Schaubroeck [102] stated, "Although outcomes of the creative process are often studied, one of the key questions in creativity research relates to the motivation of individuals to become and remain creatively engaged at work." A high degree of OID with job security ensures that employees become more curious, are receptive to challenges and risks, and exhibit extra cognitive openness and greater task persistence [84-103]. The positive influence of OID leads to employee creativity with more ease. OID breeds personal, social, and collective vitality among employees [102]. Accordingly, OID as a mediator is expected to amplify the effects of CSR on employee creativity.

Berger [19] suggests that CSR initiatives can increase employee OID and enhance organizational social identity. Bhattacharya [104] found that an individual's participation in a second organization was negatively related to his or her identification with a primary organization. According to the group engagement model [55], integration of the group identity (e.g., prestige) with one's self-concept (i.e., organizational identification) is essential. Thus, organizational identification is proposed to mediate the relationship between CSR and employee creative performance.

Hypothesis 4 (H4): There is a positive relationship between corporate social responsibility and creative performance through the mediation of organizational identification.

\subsection{OID, Creative Performance, and Creative Self-Efficacy}

CSR has a direct positive influence on employee creativity. Creative self-efficacy can be taken as the augmenting factor, along with OID, that enhances the effect of CSR on creative performance. Creative self-efficacy may also reflect intrinsic motivation to engage in creative activities; as such, it should be a powerful precursor to creativity [30] moderating the influence of organizational identification developed through company's CSR.

Creative self-efficacy has been used as a moderator in this study for three reasons. First, self-efficacy has been found to be a vital driver of performance in a variety of task domains and shows researchers' interest in creativity and the domain-specific nature of self-efficacy [105]. Employee creative self-efficacy is also the psychological mechanism behind creativity. Second, research 
has also shown that employees tend to be more creative when they have higher levels of creative self-efficacy [91,92]. Thirdly, individuals show high creative performance when creative self-efficacy amalgamates with high organizational identification [106]. Inventive leaders stimulate creative proficiency in employees for effectual creative performance when they have high organizational identification [86].

Organizational identification should be directly related to employee engagement. This model suggests that individuals who strongly identify with their organization are intrinsically motivated to support the success and viability of their organization, because of the integration of the organization and their self-concept [60]. Individuals who strongly identify with the organization are inherently interested in the organization's welfare, and therefore, this model suggests they are more willing to display extra role behaviors to promote the organization's welfare [107]. Organizational identification will partially mediate the relationship between CSR and employee creative performance [108]. Self-perception of high creative efficiency among employees directs them to involve in better creative outcomes [102].

Hypothesis 5 (H5): There is a significant positive relationship between organizational identification and creative performance when moderated by creative self-efficacy.

\subsection{CSR, Creative Performance, and Creative Self-Efficacy}

CSR plays an important role in employee recruitment [109]. Companies with good CSR reputations attract more applicants [110]. CSR investment contributes to desired economic and consumer responses, but external CSR movements can contribute internally, to [24]. For example, CSR attracts talented, competitive, and prospective workers [111,112] with high creative self-efficacy, and hence boosts innovative employee performance [113].

Limited studies have been conducted on why some individuals are particularly interested in companies that engage in CSR. Jones [110] tested two mechanisms-person-organization fit and signaling - to test the attraction of CSR for job seekers. Madjar [29] empirically found that employees' positive mood states and creative personality characteristics mediate and moderate creative performance, respectively. Research has also established that individuals with creative personalities exhibit higher creativity than those with less creative personalities [114]. Moreover, theoretical work has suggested that personality characteristics could influence the effects of social conditions on individuals' creativity [37-115]. Gong [30] scrutinized the positive relationship between employee creativity and job performance with the help of two learning-related personal and situational variables-employee learning orientation and transformational leadership—which had a collaborative effect on employee creativity through employee creative self-efficacy.

Benjamin and Flynn [31] chose transformational leadership and employee learning orientation as predictors of employee creativity, because both these variables have the potential to build up the creative proficiency among employees through them learning different approaches that enhance creative ability [32]. Motivational and inspirational drive is necessary for employee creativity in work [83-101]. However, mere motivation is not sufficient. Rather, other factors related to intrinsic capabilities such as self-efficiencies or an employee's perceptional experience of their organization, also affect the development of creativity in an employee's work.

Hypothesis 6 (H6): There is a significant positive relationship between corporate social responsibility and creative performance when moderated by creative self-efficacy. 


\section{Research Methodology}

This study is an explanatory study. Statistical techniques have been used on numerical data to conclude useful results [116], as is suitable for the business and scientific community [117]. The quantitative approach has been used to determine the significance of the relationship between CSR, organizational identification, creative self-efficacy, and creative performance. SPSS (Statistical Package for the Social Science) was used for data analysis techniques to test the hypothesis. Questionnaires' reliability was tested to ensure the soundness of measures. The reliability of any measure is dependent on ensuring the uniformity of the measure in different situations. It shows the similar manner of each item in the scale holistically [118]. A level indicates high reliability when its response is identical in identical situations. The target population for data collection was the companies practicing CSR in Pakistan; the employees of those companies were a unit of analysis for this study. The National Forum for Environment and Health (NHEF) conducted their "11th Annual Environment Excellence Awards 2014", and there were 186 nominations of CSR companies for this award. According to Sekaran [118], 35\% of the target population is considered entirely appropriate for simple random sampling, which becomes 65 companies for this study. After making the list of 186 CSR nominated companies, 65 casual enterprises were taken using the random number generator [119]. Survey response was taken through self-administered questionnaires by sending emails (Google Form) to companies, and by visiting their offices. A total of 350 inquiries were received, of which 322 questionnaires were complete and usable for data analysis. The questionnaire measures were regarding CSR, organizational identification, creative self-efficacy, and creative performance. CSR has been assessed by adopting the scale of Fatma [74]. This scale contained a total of 17 items, which are further categorized in five sub-dimensions of CSR.

A pilot study was also conducted to check the appropriation of the questionnaire being used for the study. Furthermore, standard deviation, kurtosis, and skewness have been calculated for descriptive analysis for better understanding of the data collected. The suitable range for skewness is considered as \pm 1 to \pm 3 , and for kurtosis is +1 to -1 . Correlation and simple linear regression has been applied to test the intensity of the relationship between CSR, organizational identification, creative performance, and creative self-efficacy.

\section{Results and Discussion}

Table 2 represents gender frequency distribution, percentage, and cumulative percentage. According to Table 2, male respondents made up 63\% (203) of total respondents, and 37\% (119) of the respondents were female among a total of 322 respondents, which shows that male respondents gave their response more eagerly than females.

Table 2. Gender Distribution of the Respondents $(\mathrm{N}=322)$.

\begin{tabular}{cccc}
\hline Category & Frequency & Percentage & Cumulative Percentage \\
\hline Male & 203 & 63 & 63 \\
Female & 119 & 37 & 100 \\
Total & 322 & 100 & 100 \\
\hline
\end{tabular}

Table 3 shows age frequency distribution, percentage, and cumulative percentage of the respondents. According to the results, 3.9\% (29) respondents were between 20-29 years old, 28.3\% (91) respondents were $30-39$ years old, $37.3 \%$ (120) respondents were between $40-49$ years old, and $25.5 \%$ (82) respondents were more than 50 years old. It shows that the respondents who were between 20-29 years old participated the least, whereas the 40-49-year-old respondents participated in a large number. 
Table 3. Age Distribution of the Respondents $(\mathrm{N}=322)$.

\begin{tabular}{cccc}
\hline Category & Frequency & Percentage & Cumulative Percentage \\
\hline 20-29 years & 29 & 9.0 & 9.0 \\
30-39 years & 91 & 28.3 & 37.3 \\
40-49 years & 120 & 37.3 & 74.5 \\
50+ years & 82 & 25.5 & 100.0 \\
Total & 322 & 100.0 & \\
\hline
\end{tabular}

Table 4 shows employees' experience frequency distribution, percentage, and cumulative percentage. In this study, 29.2\% (94) respondents had less than one year of experience, $43.2 \%$ (139) respondents had 1 to 3 years' experience, 25.8\% (83) respondents had 4-5 years' experience, and only $1.9 \%$ (6) respondents had more than five years of experience. It shows that the respondents with between 1-3 years of experience in the current organization participated the most, whereas the respondents with more than five years' experience were the least involved.

Table 4. Experience Distribution of the Respondents.

\begin{tabular}{cccc}
\hline Category & Frequency & Percentage & Cumulative Percentage \\
\hline Less than $\mathbf{1}$ year & 94 & 29.2 & 29.2 \\
\hline $\mathbf{1}$ to 3 years & 139 & 43.2 & 72.4 \\
\hline 4 to 5 years & 83 & 25.8 & 98.1 \\
\hline More than 5 years & 6 & 1.9 & 100.0 \\
\hline Total & 322 & 100.0 & \\
\hline
\end{tabular}

Table 5 represents the descriptive statistics for all the variables of the study. It shows mean values, standard deviations, skewness, and kurtosis for all the variables under study. The range of skewness is \pm 1 to \pm 3 , and for kurtosis is +1 to -1 . So, Table 5 shows that all the skewness and kurtosis values lie within the range. It means that the data is standard. Mean values of CSR, organizational identification, creative self-efficacy, and creative performance are 3.5223, 3.5243, 3.5569, and 3.3944, respectively. The standard deviation value of organizational identification is 1.22242, which is higher than the other variables, and explains that it is less reliable. The standard deviation value of CSR is 0.97104, which is smallest among the variables, which clarifies that it is most reliable. Values in Table 5 are measured on a Likert scale.

Table 5. Descriptive Statistics of All Variables $(\mathrm{N}=322)$. CSR: corporate social responsibility; OID: organizational identification; CSEF: creative self-efficacy; CP: creative performance.

\begin{tabular}{ccccc}
\hline Variables & Mean & S. D & Skewness & Kurtosis \\
\hline CSR & 3.5223 & 0.97104 & -0.849 & -0.344 \\
OID & 3.5243 & 1.22242 & -0.825 & -0.947 \\
CSEF & 3.5569 & 1.21133 & -0.913 & -0.712 \\
CP & 3.3944 & 1.05556 & -0.686 & -0.926 \\
Valid N (listwise) 322 & & & & \\
\hline
\end{tabular}

\subsection{Correlation Matrix}

Table 6 shows a correlation between all the variables under study. This correlation matrix explains that CSR has a significant positive relationship with organizational identification, creative self-efficacy, and creative performance with $r$-values of $0.411,0.544$, and 0.813 , respectively, with $p<0.05$. Similarly, organizational identification also has a significant positive correlation with creative self-efficacy and creative performance, with $r$-values of 0.721 and 0.404 , respectively with $p<0.05$. In the same way, 
creative performance also has a significant positive correlation with creative self-efficacy, with an $r$-value of 0.512 and $p<0.05$.

Table 6. Correlation Matrix.

\begin{tabular}{ccccc}
\hline Variables & CSR & OID & CSEF & CP \\
\hline CSR & 1 & & & \\
OID & $0.411^{* *}$ & 1 & & \\
CSEF & $0.544^{* *}$ & $0.721^{* *}$ & 1 & \\
CP & $0.813^{* *}$ & $0.404^{* *}$ & $0.512^{* *}$ & 1 \\
\hline \multicolumn{5}{c}{$p<0.05}$.
\end{tabular}

\subsection{Scale Reliability}

In this study, the reliability of all four scales was checked through Cronbach's alpha coefficients. Table 7 shows the value of Cronbach's alpha coefficients, which were $0.941,0.965,0.842$, and 0.918 for CSR, organizational identification, creative self-efficacy, and creative performance, respectively.

Table 7. Cronbach's Alpha Reliability Coefficients of All Scales $(\mathrm{N}=30)$.

\begin{tabular}{ccc}
\hline Variables & No. of Items & Cronbach's Alpha \\
\hline Corporate Social Responsibility & 17 & 0.941 \\
Organizational Identification & 6 & 0.965 \\
Creative Self-Efficacy & 4 & 0.842 \\
Creative Performance & 3 & 0.918 \\
Total & 30 & \\
\hline
\end{tabular}

\subsection{Dependent Variable: OID}

The value of Cronbach's alpha coefficients for different sets of items is depicted in Table 7. It is more than 0.8. This value is far exceeding the minimum level of 0.7 [120]. A value of 0.6 or less is considered to depict unsatisfactory internal consistency. CSR has 17 items that were measured for reliability. A Cronbach's alpha value of closer to 1 shows higher internal consistency reliability. For further statistical analysis, these reliability tests predict a satisfactorily high level of internal consistency. All the values are quite near to 1 , so all the scales used in the study are considered appropriate and reliable.

\subsection{Simple Linear Regression}

Simple linear regression has been applied to check the intensity of each relationship between CSR, organizational identification, creative self-efficacy, and creative performance.

Table 8 represents the relationship between CSR and OID. The relationship is significant, with a $p$-value of 0.000 and a beta value of $51 \%(0.517)$, which explains that there is a positive and direct relationship between CSR and OID. The overall model is a good fit with F value 64.963, and the adjusted $\mathrm{R}^{2}$ value is $16 \%(0.166)$. The $\mathrm{H}_{1}$ hypothesis has been accepted in this article.

Table 8. CSR and OID.

\begin{tabular}{ccccc}
\hline & B SE & Adj. $\mathbf{R}^{2} \mathbf{F}$ & $\mathbf{t}$ & $p$ \\
\hline Constant & 1.7030 .234 & 0.16664 .963 & 7.265 & 0.000 \\
CSR & 0.5170 .064 & & 8.060 & 0.000 \\
\hline \multicolumn{5}{c}{ Dependent Variable: OID. }
\end{tabular}


Table 9 represents the intensity of the relationship between OID and creative performance (CP). The association is significant, with a $p$-value of 0.000 and a beta value of $71 \%(0.715)$, which explains that there is a definite and direct relationship between OID and CP. The overall model is a good fit with $F$ value 346.856 , and the adjusted $R^{2}$ value is approximately $52 \%(0.519)$. Thus, the $\mathrm{H}_{2}$ hypothesis has been accepted.

Table 9. OID and CP.

\begin{tabular}{cccccc}
\hline & B & SE & Adj. $\mathbf{R}^{\mathbf{2}} \mathbf{F}$ & $\mathbf{t}$ & $\boldsymbol{p}$ \\
\hline Constant & 1.038 & 0.143 & 0.519346 .856 & 7.254 & 0.000 \\
OID & 0.715 & 0.038 & & 18.624 & 0.000 \\
\hline \multicolumn{5}{c}{ Dependent Variable: CP. }
\end{tabular}

\subsection{Creative Self-Efficacy (CSEF) and CP}

Table 10 shows the intensity of the relationship between creative self-efficacy (CSEF) and CP. The relationship is significant, with a $p$-value of 0.000 and a beta value of $58 \%(0.587)$, which explains that there is a positive and direct relationship between CSEF and CP. The overall model is a good fit with F value 113.503 , and the adjusted $\mathrm{R}^{2}$ value is $26 \%(0.260)$. The $\mathrm{H}_{3}$ hypothesis has been accepted in this study.

Table 10. CSEF and CP Relationship.

\begin{tabular}{ccccc}
\hline & B SE & Adj. $\mathbf{R}^{\mathbf{2}} \mathbf{F}$ & $\mathbf{t}$ & $\boldsymbol{p}$ \\
\hline Constant & 1.5630 .196 & 0.260113 .503 & 7.982 & 0.000 \\
CSEF & 0.5870 .055 & & 10.654 & 0.000 \\
\hline \multicolumn{5}{c}{ Dependent Variable: CP. }
\end{tabular}

\subsection{Mediation}

Barron and Kenny's tests were applied to investigate the mediating effect of organizational identification on the relationship between CSR and creative performance.

\section{Path Analysis}

Figure 2 shows the relationship of the mediator and the dependent and independent variables. Figure 2a represents OID as a mediator between CSR and CP. Figure $2 b$ shows the direct path between CSR and creative performance (CP). The analysis will show whether there is full mediation, partial mediation, or no mediation. Figure $2 b$ also shows the direct effect of CSR on creative performance.

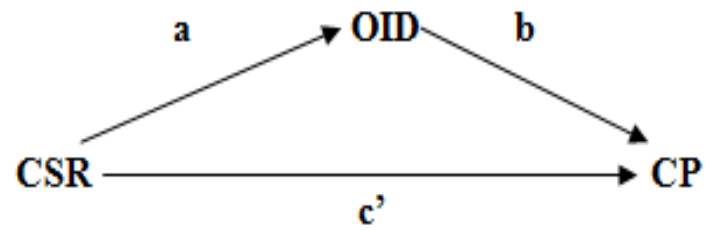

(a)

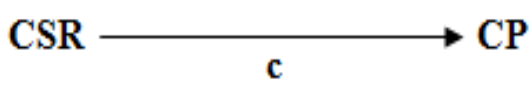

(b)

Figure 2. (a): Indirect Path; (b): Direct Path.

According to Table 11, all the paths of mediation (a, b, $c$ and $\left.c^{\prime}\right)$ are fulfilling the condition and showing partial mediation. CSR has a significant positive association with organizational identification 
(a path), with a $p$-value of 0.000 . Similarly, organizational identification also has a significant positive association with creative performance (b path), with a $p$-value of 0.000 .

Table 11. Mediation.

\begin{tabular}{ccccc}
\hline Paths & Coefficients & SE & t & $p$ \\
\hline CSR to OID (a path) & 0.5171 & 0.0642 & 8.06 & 0 \\
OID to CP (b path) & 0.5931 & 0.0388 & 15.3012 & 0 \\
Direct effect of CSR on CP (c' path) & 0.3725 & 0.0488 & 7.6343 & 0 \\
Total effect of CSR on CP (c path) & 0.6792 & 0.0585 & 11.6127 & 0 \\
\hline
\end{tabular}

Adj. $R^{2}=0.5917, F=233.6138$.

There is a significant positive relationship between CSR and creative performance. It has a $p$-value of 0.000 , and the larger coefficient value (0.6792) of the total effect (c path) than the coefficient value (0.3725) of direct effect ( $c^{\prime}$ path) shows that there is a partial mediation of organizational identification between the relationship of CSR and creative performance. Therefore, the fourth hypothesis $\left(\mathrm{H}_{4}\right)$ in this study has been accepted.

\subsection{Moderation}

Hierarchical regression was applied to investigate the moderating effect of creative self-efficacy on the relationship between organizational identification and creative performance.

\subsubsection{OID, CSEF, and CP}

Table 12 shows the values of $R^{2}$, the adjusted $R^{2}$, and the $F$ values at the relevant level of significance for Model 1, which does not have an interaction term, and Model 2, which is an interaction term. The value of the change in adjusted $R^{2}$ is $\Delta$ Adj. $R^{2}=0.008$, with a change in $F$ value $\Delta F=67.411$ and a $p$-value of 0.000 . It explains that there is $0.8 \%$ additional variance in creative performance by adding creative self-efficacy as a moderator. Both models are significant, with a $p$-value of 0.000 . The $\mathrm{F}$ value is 218.629 in Model 1, and 151.218 in Model 2.

Table 12. Model Significance.

\begin{tabular}{ccccc}
\hline Model & $\mathbf{R}^{\mathbf{2}}$ & Adj. $\mathbf{R}^{\mathbf{2}}$ & $\mathbf{F}$ & $\boldsymbol{p}$ \\
\hline 1 & 0.578 & 0.576 & 218.629 & 0.000 \\
2 & 0.588 & 0.584 & 151.218 & 0.000 \\
Difference & 0.01 & 0.008 & 67.411 & \\
\hline
\end{tabular}

Table 13 shows the moderating effect of creative self-efficacy between organizational identification and creative performance, with a beta value of 0.117 and a $p$-value of 0.007 . Hence, creative self-efficacy has a significant moderating effect. The fifth hypothesis $\left(\mathrm{H}_{5}\right)$ in this study has been accepted.

Table 13. Moderation.

\begin{tabular}{cccc}
\hline & B SE & $\mathbf{t}$ & $\boldsymbol{p}$ \\
\hline Constant & 0.6880 .199 & 3.456 & 0.001 \\
OID & 0.5810 .040 & 14.381 & 0 \\
CSEF & 0.2570 .048 & 5.345 & 0 \\
OID * CSEF & 0.1170 .043 & 2.738 & 0.007 \\
\hline
\end{tabular}

\subsubsection{CSR, CSEF, and CP}

Table 14 shows the values of $R^{2}$, the adjusted $R^{2}$, and the $F$ values at the relevant level of significance for Model 1, which does not have an interaction term, and Model 2, which is an interaction 
term. The value of the change in adjusted $R^{2}$ is $\Delta$ Adj. $R^{2}=0.002$, with a change in $F$ value $\Delta F=23.404$ and a $p$-value of 0.000 . It explains that there is much less additional variance in creative performance by adding creative self-efficacy as a moderator when the independent variable is CSR.

Table 14. CSR, CSEF, and CP Model Significance.

\begin{tabular}{ccccc}
\hline Model & $\mathbf{R}^{\mathbf{2}}$ & Adj. $\mathbf{R}^{\mathbf{2}}$ & $\mathbf{F}$ & $\boldsymbol{p}$ \\
\hline 1 & 0.311 & 0.306 & 71.232 & 0.000 \\
2 & 0.311 & 0.304 & 47.828 & 0.000 \\
Difference & 0 & 0.002 & 23.404 & \\
\hline
\end{tabular}

Table 15 shows the moderating effect of creative self-efficacy between CSR and creative performance with a beta value of -0.027 and a $p$-value of 0.667 . Hence, creative self-efficacy has an insignificant moderating effect. Therefore, sixth hypothesis $\left(\mathrm{H}_{6}\right)$ in this study has not been accepted.

Table 15. Creative Self-Efficacy, CSR and Creative Performance Moderation.

\begin{tabular}{cccc}
\hline & B SE & $\mathbf{t}$ & $p$ \\
\hline Constant & 1.2210 .355 & 3.442 & 0.001 \\
CSR & 0.4540 .109 & 4.153 & 0 \\
CSEF & 0.2250 .094 & 2.387 & 0.018 \\
CSR * CSEF & -0.0270 .062 & -0.430 & 0.667 \\
\hline
\end{tabular}

\section{Conclusions}

This study has concluded that employees who value CSR campaigns and its other activities and practices to a higher degree have stronger intentions to stay in the organization, with more engagement and loyalty due to their enhanced organizational identification. Furthermore, employees with high corporate identification show more loyal attitudes in their work in relation to the organization's success, and work with more devotion and intention to support organizational objectives. Results also suggest that employees with more creative personalities and creative self-efficacy tend to give high-quality creative performances. Therefore, this study has contributed to the literature by examining the impact of CSR on creative performance with the help of the mediating role of organizational identification and the moderating effect of creative self-efficacy.

\section{Implications}

The findings of this article show that CSR has an extraordinary influence on employee attitudes and behaviors, as it motivates them to express a higher quality creative performance. Organizations are focusing on creativity in employee performance for better career development and innovation [101]. This study has implications for organizational managers and leaders, because they are currently facing the challenge of indulging employees in creative work performance activities [28].

Secondly, creative self-efficacy also imitates employees' intrinsic motivations to perform creative roles, and is used as a powerful precursor to creativity [30]. The findings of this paper suggest that organizational managers and leaders should focus on developing and improving creative self-efficacy among employees. Since employees' work attitudes can be profoundly influenced, more significant results may come if they have confidence in their aptitude to perform that work [121]. Furthermore, the employees with higher creative self-efficacy tend to accept challenges to perform activities and act upon new and creative practices.

Thirdly, employees usually prefer their working organizations to run their business activities in compliance with social responsibility practices [15], which increases their level of organizational identification. Moreover, employee engagement is being ensured as far as CSR becomes embedded in the organization [11]. This study suggests that information regarding organizational CSR practices 
must be conveyed to the employees, because they make a holistic judgment and evaluation from every aspect of their organizations in developing their attitudinal and behavioral responses, which ultimately pushes them to work with more devotion and creativity [24].

Author Contributions: All authors contributed equally to this research.

Conflicts of Interest: The authors declare no conflict of interest.

\section{References}

1. Crowther, D.; Rayman-Bacchus, L. (Eds.) Perspectives on Corporate Social Responsibility; Ashgate: Aldershot, UK, 2004.

2. Freeman, R.E.; Reed, D.L. Stockholders and stakeholders: A new perspective on corporate governance. Calif. Manag. Rev. 1983, 25, 88-106. [CrossRef]

3. Elkington, J. Cannibals with Forks: Triple Bottom Line of 21st Century Business; Capstone Publishing/John Wiley: Oxford, UK, 1997.

4. Crane, A.; Matten, D. Business Ethics, 2nd ed.; Oxford University Press: Oxford, UK, 2007.

5. Curran, J.; Rutherfoord, R.; Smith, S.L. Is there a local business community? Explaining the non-participation of small business in local economic development. Local Econ. 2000, 15, 128-143. [CrossRef]

6. Waddock, S.A.; Bodwell, C.; Graves, S.B. Responsibility: The new business imperative. Acad. Manag. Exec. 2002, 16, 132-148. [CrossRef]

7. Bass, B.M.; Steidlmeier, P. Ethics, character, and authentic transformational leadership behavior. Leadersh. Q. 1999, 10, 181-217. [CrossRef]

8. Hillenbrand, C.; Money, K.; Pavelin, S. Stakeholder-defined corporate responsibility for a pre-credit-crunch financial service company: Lessons for how good reputations are won and lost. J. Bus. Ethics 2012, 105, 337-356. [CrossRef]

9. Hillenbrand, C.; Money, K.; Ghobadian, A. Unpacking the mechanism by which corporate responsibility impacts stakeholder relationships. Br. J. Manag. 2013, 24, 127-146. [CrossRef]

10. Rupp, D.E.; Ganapathi, J.; Aguilera, R.V.; Williams, C.A. Employee reactions to corporate social responsibility: An organizational justice framework. J. Organ. Behav. 2006, 27, 537-543. [CrossRef]

11. Jenkins, H. Small business champions for corporate social responsibility. J. Bus. Ethics 2006, 67, 241-256. [CrossRef]

12. Duberley, J.P.; Walley, P. Assessing the adoption of HRM by small and medium-sized manufacturing organizations. Int. J. Hum. Resour. Manag. 1995, 6, 891-909. [CrossRef]

13. Kotey, B.; Slade, P. Formal human resource management practices in small growing firms. J. Small Bus. Manag. 2005, 43, 16-40. [CrossRef]

14. Davies, I.A.; Crane, A. Corporate social responsibility in small and medium-sized enterprises: Investigating employee engagement in fair trade companies. Bus. Ethics 2010, 19, 126-139. [CrossRef]

15. Yoon, Y.; Gürhan-Canli, Z.; Schwarz, N. The effect of corporate social responsibility (CSR) activities on companies with bad reputations. J. Consum. Psychol. 2006, 16, 377-390. [CrossRef]

16. McWilliams, A.; Siegel, D. Corporate social responsibility: A theory of the firm perspective. Acad. Manag. Rev. 2001, 26, 117-127.

17. Jones, D.A. Does serving the community also serve the company? Using organizational identification and social exchange theories to understand employee responses to a volunteerism programme. J. Occup. Organ. Psychol. 2010, 83, 857-878. [CrossRef]

18. Kim, H.-R.; Lee, M.; Lee, H.-T.; Kim, N.-M. Corporate social responsibility and employee-company identification. J. Bus. Ethics 2010, 95, 557-569. [CrossRef]

19. Berger, I.E.; Cunningham, P.H.; Drumwright, M.E. Identity, identification, and relationship through social alliances. J. Acad. Mark. Sci. 2006, 34, 128-137. [CrossRef]

20. Brammer, S.; Millington, A.; Rayton, B. The contribution of corporate social responsibility to organizational commitment. Int. J. Hum. Resour. Manag. 2007, 18, 1701-1719. [CrossRef]

21. Bhattacharya, C.B.; Sen, S.; Korschun, D. Using corporate social responsibility to win the war for talent. MIT Sloan Manag. Rev. 2008, 49, 37-44. 
22. Greening, D.W.; Turban, D.B. Corporate social performance as a competitive advantage in attracting a quality workforce. Bus. Soc. 2000, 39, 254-280. [CrossRef]

23. Aqueveque, C.; Encina, C. Corporate behavior, social cynicism, and their effect on individuals' perceptions of the company. J. Bus. Ethics 2010, 91, 311-324. [CrossRef]

24. Brammer, S.; He, H.; Mellahi, K. Corporate Social Responsibility, Employee Organizational Identification, and Creative Effort The Moderating Impact of Corporate Ability. Group Organ. Manag. 2015, 40, 323-352. [CrossRef]

25. Drazin, R.; Glynn, M.A.; Kazanjian, R.K. Multilevel theorizing about creativity in organizations: Sensemaking perspective. Acad. Manag. Rev. 1999, 24, 286-307.

26. Zhu, Y.; Sun, L.Y.; Leung, A.S. Corporate social responsibility, firm reputation, and firm performance: The role of ethical leadership. Asia Pac. J. Manag. 2014, 31, 925-947. [CrossRef]

27. Amabile, T.M. How to kill creativity. Harv. Bus. Rev. 1998, 76, 77-87.

28. Atwater, L.; Carmeli, A. Leader-member exchange, feelings of energy, and involvement in creative work. Leadersh. Q. 2009, 20, 264-275. [CrossRef]

29. Madjar, N.; Oldham, G.R.; Pratt, M.G. There's no place like home? The contributions of work and nonwork creativity support to employees' creative performance. Acad. Manag. J. 2002, 45, 757-767. [CrossRef]

30. Gong, Y.; Huang, J.C.; Farh, J.L. Employee learning orientation, transformational leadership, and employee creativity: The mediating role of employee creative self-efficacy. Acad. Manag. J. 2009, 52, 765-778. [CrossRef]

31. Benjamin, L.; Flynn, F.J. Leadership style and regulatory mode: Value from fit? Organ. Behav. Hum. Decis. Process. 2006, 100, 216-230. [CrossRef]

32. Amabile, T.M.; Gryskiewicz, S.S. Creativity in the RED Laboratory; Technical Report Number 30; Center for Creative Leadership: Greensboro, NC, USA, 1987.

33. Farmer, S.M.; Tierney, P.; Kung-McIntyre, K. Employee creativity in Taiwan: An application of role identity theory. Acad. Manag. J. 2003, 46, 618-630. [CrossRef]

34. George, J.M.; Zhou, J. Understanding when bad moods foster creativity and good ones don't: The role of context and clarity of feelings. J. Appl. Psychol. 2002, 87, 687-697. [CrossRef] [PubMed]

35. Oldham, G.R.; Cummings, A. Employee creativity: Personal and contextual factors at work. Acad. Manag. J. 1996, 39, 607-634. [CrossRef]

36. Shalley, C.E. Effects of coaction, expected evaluation, and goal setting on creativity and productivity. Acad. Manag. J. 1995, 38, 483-503. [CrossRef]

37. Amabile, T.M.; Conti, R.; Coon, H.; Lazenby, J.; Herron, M. Assessing the work environment for creativity. Acad. Manag. J. 1996, 39, 1154-1184. [CrossRef]

38. Syed, M.A.; Butt, S.A. Financial and non-financial determinants of corporate social responsibility: Empirical evidence from Pakistan. Soc. Responsib. J. 2017, 13, 780-797. [CrossRef]

39. Newman, A.; Nielsen, I.; Miao, Q. The impact of employee perceptions of organizational corporate social responsibility practices on job performance and organizational citizenship behavior: Evidence from the Chinese private sector. Int. J. Hum. Resour. Manag. 2015, 26, 1226. [CrossRef]

40. Sun, L.; Yu, T.R. The impact of corporate social responsibility on employee performance and cost. Rev. Account. Finance 2015, 14, 262-284. [CrossRef]

41. Carroll, A.B. A history of corporate social responsibility: Concepts and practices. In The Oxford Handbook of Corporate Social Responsibility; Crane, A., McWilliams, A., Matten, D., Moon, J., Siegel, D.S., Eds.; Oxford University Press: New York, NY, USA, 2008; pp. 19-46.

42. Lund-Thomsen, P. Towards a critical framework on corporate social and environmental responsibility in the south: The case of Pakistan. Development 2004, 47, 106-113. [CrossRef]

43. Cheney, G.; Tompkins, P. Coming to Terms with Organizational Identification and Commitment. Cent. States Speech J. 1987, 38, 1-15. [CrossRef]

44. Ashforth, B.E.; Mael, F. Social identity theory and the organization. Acad. Manag. Rev. 1989, 14, $20-39$.

45. Rousseau, D.M. Why workers still identify with organizations. J. Organ. Behav. 1998, 19, 217-233. [CrossRef]

46. Tajfel, H.; Turner, J.C. The social identity theory of intergroup behavior. In Psychology of Intergroup Relations, 2nd ed.; Worchel, S., Austin, W.G., Eds.; Nelson-Hall: Chicago, IL, USA, 1986; pp. 7-24.

47. Miller, V.D.; Allen, M.; Casey, M.K.; Johnson, J.R. Reconsidering the organizational identification questionnaire. Manag. Commun. Q. 2000, 13, 626-658. [CrossRef] 
48. O'Reilly, C.; Chatman, J. Organizational commitment and psychological attachment: The effects of compliance, identification, and internalization on pro-social behavior. J. Appl. Psychol. 1986, 71, 492-499. [CrossRef]

49. Dutton, J.E.; Dukerich, J.M.; Harquail, C.V. Organizational images and member identification. Adm. Sci. Q. 1994, 39, 239-263. [CrossRef]

50. Gautam, T.; Van Dick, R.; Wagner, U. Organizational identification and organizational commitment: Distinct aspects of two related concepts. Asian J. Soc. Psychol. 2004, 7, 301-315. [CrossRef]

51. Abrams, D.; Hogg, M.A. Comments on the motivational status of self-esteem in social identity and intergroup discrimination. Eur. J. Soc. Psychol. 1988, 18, 317-334. [CrossRef]

52. Burke, P.J.; Franzoi, S.L. Studying situations and identities using experiential sampling methodology. Am. Sociol. Rev. 1988, 53, 559-568. [CrossRef]

53. Korschun, D.; Bhattacharya, C.B.; Swain, S.D. Corporate social responsibility, customer orientation, and the job performance of frontline employees. J. Mark. 2014, 78, 20. [CrossRef]

54. Tolman, E.C. Identification and the post-war world. J. Abnorm. Soc. Psychol. 1943, 38, 141-148. [CrossRef]

55. Tyler, T.R.; Blader, S.L. Identity and cooperative behavior in groups. Group Process. Intergroup Relat. 2001, 4, 207-226. [CrossRef]

56. Mael, F; Ashforth, B.E. Alumni and their alma mater: A partial test of the reformulated model of organizational identification. J. Organ. Behav. 1992, 13, 103-123. [CrossRef]

57. Cropanzano, R.; Mitchell, M.S. Social exchange theory: An interdisciplinary review. J. Manag. 2005, 31, 874-900. [CrossRef]

58. Tyler, T.R.; Degoey, P.; Smith, H.J. Understanding why the fairness of group procedures matters: A test of psychological dynamics of the group-value model. J. Personal. Soc. Psychol. 1996, 70, 913-930. [CrossRef]

59. Tyler, T.R. Why people cooperate with organizations: An identity-based perspective. Res. Organ. Behav. 1999, 21, 201-246.

60. Tyler, T.R.; Blader, S.L. Cooperation in Groups: Procedural Justice, Social Identity, and Behavioral Engagement; Psychology Press: Philadelphia, PA, USA, 2000.

61. Lund-Thomsen, P.; Coe, N.M. Corporate social responsibility and labour agency: The case of Nike in Pakistan. J. Econ. Geogr. 2015, 15, 275. [CrossRef]

62. Finke, R.; Ward, T.B.; Smith, S.M. Creative Cognition: Theory, Research, and Applications; MIT Press: London, UK, 1992.

63. Ward, T.B. What's old about new ideas. In The Creative Cognition Approach; Smith, S.M., Ward, T.B., Finke, R.A., Eds.; MIT Press: London, UK, 1995; pp. 157-178.

64. Weisberg, R.W. Creativity: Beyond the Myth of Genius; WH Freeman: New York, NY, USA, 1993.

65. Staples, D.S.; Hulland, J.S.; Higgins, C.A. A self-efficacy theory explanation for the management of remote workers in virtual organizations. J. Comput.-Med. Commun. 1998, 3. [CrossRef]

66. Hameed, S.K. Corporate social responsibility (CSR) theory and practice in Pakistan. Master's Thesis, Swedish University of Agricultural Sciences, Uppsala, Sweden, 23 December 2010.

67. Stawiski, S.; Deal, J.J.; Gentry, W. Employee Perceptions of Corporate Social Responsibility: The Implications for Your Organization; Quick View Leadership Series; Center for Creative Leadership: Greensboro, NC, USA, 2010.

68. Raza, J.; Majid, A. Perceptions and practices of corporate social responsibility among SMEs in Pakistan. Qual. Quant. 2016, 50, 2625-2650. [CrossRef]

69. Yawar, H.M. CSR Pakistan Evolution, Rise, and Impact of Socio-Economic Development; Capital Business (Pvt) Ltd.: Lahore, Pakistan, 2009.

70. Visser, W.; Matten, D.; Pohl, M.; Tolhurst, N. (Eds.) The A to Z of Corporate Social Responsibility: CSR in Developing Countries; Wiley: Hoboken, NJ, USA, 2008; pp. 473-498.

71. Javaid Lone, E.; Ali, A.; Khan, I. Corporate governance and corporate social responsibility disclosure: Evidence from Pakistan. Corp. Gov. 2016, 16, 785-797. [CrossRef]

72. Gunningham, N. Green Alliances: Conflict or Cooperation in Environmental Policy; Australian Centre for Environmental Law, Faculty of Law, ANU: Canberra, Australia, 2001.

73. Carroll, A.B.; Buchholtz, A.K. Business and Society: Ethics and Stakeholder Management, 5th ed.; Thomson South-Western: Mason, OH, USA, 2003.

74. Fatma, M.; Rahman, Z.; Khan, I. Multi-Item Stakeholder-Based Scale to Measure CSR in the Banking Industry. Int. Strateg. Manag. Rev. 2014, 2, 9-20. [CrossRef] 
75. Ashforth, B.E.; Harrison, S.H.; Corley, K.G. Identification in organizations: An examination of four fundamental questions. J. Manag. 2008, 34, 325-374. [CrossRef]

76. Haslam, S.A. Psychology in Organizations: The Social Identity Approach; SAGE: London, UK, 2001.

77. Boyd, B.K.; Bergh, D.D.; Ketchen, D.J. Reconsidering the reputation-performance relationship: A resource-based view. J. Manag. 2010, 36, 588-609. [CrossRef]

78. Pfarrer, M.D.; Pollock, T.G.; Rindova, V.P. A table of two assets: The effects of firm reputation and celebrity on earnings surprises and investors' reactions. Acad. Manag. J. 2010, 53, 1131-1152. [CrossRef]

79. Highhouse, S.; Brooks, M.E.; Gregarus, G. An organizational impression management perspective on the formation of corporate reputations. J. Manag. 2009, 35, 1481-1493. [CrossRef]

80. Bauman, C.W.; Skitka, L.J. Corporate social responsibility as a source of employee satisfaction. Res. Organ. Behav. 2012, 32, 63-86. [CrossRef]

81. Hekman, D.R.; Bigley, G.A.; Steensma, H.K.; Hereford, J.F. Combined effect of organizational identification and professional identification on the reciprocity dynamic for professional employees. Acad. Manag. J. 2009, 52, 506-526. [CrossRef]

82. Zhou, J. When the presence of creative coworkers is related to creativity: Role of supervisor close monitoring, developmental feedback, and creative personality. J. Appl. Psychol. 2003, 88, 413-422. [CrossRef] [PubMed]

83. Zhou, J.; Shalley, C.E. Expanding the scope and impact of organizational creativity research. In Handbook of Organizational Creativity; Zhou, J., Shalley, C.E., Eds.; Lawrence Erlbaum: New York, NY, USA, 2008; pp. 347-368.

84. Grant, A.M.; Berry, J.W. The necessity of others is the mother of invention: Intrinsic and prosocial motivations, perspective taking, and creativity. Acad. Manag. J. 2011, 54, 73-96. [CrossRef]

85. Walumbwa, F.O.; Mayer, D.M.; Wang, P.; Wang, H.; Workman, K.; Christensen, A.L. Linking ethical leadership to employee performance: The roles of leader-member exchange, self-efficacy, and organizational identification. Organ. Behav. Hum. Decis. Process. 2011, 115, 204-213. [CrossRef]

86. Hirst, G.; van Dick, R.; van Knippenberg, D. A social identity perspective on leadership and employee creativity. J. Organ. Behav. 2009, 30, 963-982. [CrossRef]

87. Hogg, M.A.; van Knippenberg, D. Social identity and leadership processes in teams. In Advances in Experimental Social Psychology; Zanna, M.P., Ed.; Academic Press: San Diego, CA, USA, 2003; Volume 35, pp. 1-52.

88. Shin, S.; Zhou, J. When is educational specialization heterogeneity related to creativity in research and development teams? Transformational leadership as a moderator. J. Appl. Psychol. 2007, 92, 1709-1721. [CrossRef] [PubMed]

89. Egan, T.M. Factors influencing individual creativity in the workplace: An examination of quantitative empirical research. Adv. Dev. Hum. Resour. 2005, 7, 160-181. [CrossRef]

90. Lemons, G.K. A qualitative investigation of college students' creative self-efficacy. Ph.D. Thesis, University of Northern Colorado, Greeley, CO, USA, 2005.

91. Tierney, P.; Farmer, S.M. Creativity self-efficacy: Its potential antecedents and relationship to creative performance. Acad. Manag. J. 2002, 45, 1137-1148. [CrossRef]

92. Tierney, P.; Farmer, S.M. The Pygmalion process and employee creativity. J. Manag. 2004, 30, $413-432$. [CrossRef]

93. Ma, X. Examining the Effects of Individual's Polychronicity and Supervisor's Management Style on Creative Self-Efficacy. Master's Thesis, Victoria University of Wellington, Wellington, New Zealand, April 2008.

94. Hall, E.T.; Hall, M.R. Understanding Cultural Differences: Germans, French, and Americans; Hardback; Yarmouth, M.E., Ed.; Intercultural Press: Boston, MA, USA, 1990; 196p, ISBN 0-933662-84-X.

95. Tierney, P.; Farmer, S.M.; Graen, G.B. An examination of leadership and employee creativity: The relevance of traits and relationships. Pers. Psychol. 1999, 52, 591-620. [CrossRef]

96. Houghton, J.D.; DiLiello, T.C. Leadership development: The key to unlocking individual creativity in organizations. Leadersh. Organ. Dev. J. 2010, 31, 230-245. [CrossRef]

97. Yu, C. The relationship between undergraduate students' creative self-efficacy, creative ability, and career self-management. Int. J. Acad. Res. Progress. Educ. Dev. 2013, 2, 181-193.

98. Pérez, A. Corporate reputation and CSR reporting to stakeholders: Gaps in the literature and future lines of research. Corp. Commun. 2015, 20, 11-29. [CrossRef]

99. Mishra, S.; Suar, D. Does corporate social responsibility influence firm performance of Indian companies? J. Bus. Ethics 2010, 95, 571-601. [CrossRef] 
100. Okamoto, D. Social relationship of a firm and the CSP-CFP relationship in Japan: Using artificial neural networks. J. Bus. Ethics 2009, 87, 117-132. [CrossRef]

101. Amabile, T.M. A model of creativity and innovation in organizations. In Research in Organizational Behavior; Staw, B.M., Cummings, L.L., Eds.; JAI Press: Greenwich, CT, USA, 1988; Volume 10, pp. 123-167.

102. Carmeli, A.; Schaubroeck, J. The influence of leaders' and other referents' normative expectations on individual involvement in creative work. Leadersh. Q. 2007, 18, 35-48. [CrossRef]

103. Amabile, T.M.; Barsade, S.G.; Mueller, J.S.; Staw, B.M. Affect and creativity at work. Adm. Sci. Q. 2005, 50, 367-403. [CrossRef]

104. Bhattacharya, C.B.; Rao, H.; Glynn, M.A. Understanding the bond of identification: An investigation of its correlates among art museum members. J. Mark. 1995, 59, 46-57. [CrossRef]

105. Bandura, A. Self-efficacy: Toward a unifying theory of behavioral change. Psychol. Rev. 1977, 84, $191-215$. [CrossRef] [PubMed]

106. Wang, P.; Rode, J.C. Transformational leadership and follower creativity: The moderating effects of identification with the leader and organizational climate. Hum. Relat. 2010, 63, 1105-1128. [CrossRef]

107. Blader, S.L.; Tyler, T.R. Testing and extending the group engagement model: Linkages between social identity, procedural justice, economic outcomes, and extra-role behavior. J. Appl. Psychol. 2009, 94, 445-464. [CrossRef] [PubMed]

108. Smith, T.E. Thinking Contemporary Curating; Independent Curators International: New York, NY, USA, 2012; pp. 249-258.

109. Aiman-Smith, L.; Bauer, T.N.; Cable, D.M. Are you attracted? Do you intend to pursue? A recruiting policy-capturing study. J. Bus. Psychol. 2001, 16, 219-237. [CrossRef]

110. Jones, D.A.; Wellness, C.; Macneil, S. Corporate Social Responsibility and Recruitment: Testing Person-Organization Fit and Signaling Mechanisms. In Academy of Management Proceedings; Academy of Management: Briarcliff Manor, NY, USA, 2009; Volume 2009, pp. 1-6.

111. Collings, D.G.; Mellahi, K. Strategic talent management: A review and research agenda. Hum. Resour. Manag. Rev. 2009, 19, 304-313. [CrossRef]

112. Turban, D.B.; Greening, D.W. Corporate social performance and organizational attractiveness to prospective employees. Acad. Manag. J. 1997, 40, 658-672. [CrossRef]

113. Homburg, C.; Wieseke, J.; Hoyer, W.D. Social identity and the service-profit chain. J. Mark. 2009, 73, 38-54. [CrossRef]

114. Feist, G.J. The influence of personality on artistic and scientific creativity. In Handbook of Creativity; Sternberg, R., Ed.; Cambridge University Press: Cambridge, UK, 1999; pp. 273-296.

115. Woodman, R.W.; Sawyer, J.E.; Griffin, R.W. Toward a theory of organizational creativity. Acad. Manag. Rev. 1993, 18, 293-321.

116. Punch, S. The generation of power: A comparison of child-parent and sibling relations in Scotland. Sociol. Stud. Child. Youth 2005, 10, 169-188.

117. Amram, Y.; Dryer, C. The Integrated Spiritual Intelligence Scale (ISIS): Development and Preliminary Validation. Available online: https://www.researchgate.net/publication/228385379_The_Integrated_Spiritual_ Intelligence_Scale_ISIS_Development_and_preliminary_validation (accessed on 12 November 2017).

118. Sekaran, U. Research Methods for Business: A Skill Building Approach; John Willey and Sons: New York, NY, USA, 2003.

119. Destination for Math Education. Available online: www.mathgoodies.com (accessed on 12 July 2017).

120. Pallant, J. SPSS Survival Manual: A Step by Step Guide to Data Analysis Using SPSS for Windows; Version 10; Allen \& Unwin: St Leonards, Australia, 2001.

121. Bandura, A.; Adams, N.E.; Hardy, A.B.; Howells, G.N. Tests of the generality of self-efficacy theory. Cogn. Ther. Res. 1980, 4, 39-66. [CrossRef]

(C) 2017 by the authors. Licensee MDPI, Basel, Switzerland. This article is an open access article distributed under the terms and conditions of the Creative Commons Attribution (CC BY) license (http:/ / creativecommons.org/licenses/by/4.0/). 